\title{
The Contested Politics of Environmental Rulemaking
}

\author{
Colin Provost \\ School of Public Policy/Department of Political Science \\ University College London
}

Brian J. Gerber

College of Public Service and Community Solutions

Arizona State University 


\section{Introduction}

This chapter examines in detail environmental rulemaking in the United States. Rulemaking's current from derives from the 1946 Administrative Procedure Act (APA), which provides the means through which existing laws are translated by agencies into more specific and detailed rules. The APA provides that bureaucratic agencies are the source of these rules, which are just as legally binding as laws passed by Congress (Kerwin and Furlong 2019). These rules, while they may seem technocratic and arcane to the general public, are in fact highly salient as they help to determine, for example, acceptable levels of certain pollutants in the air we breathe or water we drink, while also estimating how expensive regulatory compliance costs will be for businesses. In other words, rules have tremendous power for redistributing and reshaping the costs and benefits of environmental protection more broadly.

Most current scholarship on environmental rulemaking deals with the period of 1970 onward when the Environmental Protection Agency (EPA) was created and the issue of environmental protection gained traction as a highly contested and salient issue in American politics. A central question underlying much of this research is how rulemaking bureaucrats are held accountable by their various audiences and constituencies in business, environmental advocacy groups, the White House, Congress and the courts. Because the environment is an important, yet polarizing issue in the United States (see Antonio and Brulle 2011; Dunlap et al. 2016), federal agencies frequently find themselves under attack, depending on who is in power, for producing rules too slowly, for failing to take into account all relevant considerations or for being easily influenced by big business. 
In this chapter, we examine these competing forces that attempt to bring pressure to bear on agencies like the EPA ${ }^{1}$, and how these forces have altered the structure and outputs of rulemaking agencies. Because the redistributive impacts of environmental rulemaking can be so significant, much of the institutional churn and debate has often focused on altering the costs and benefits of regulation. More specifically, nearly every president since Gerald Ford has taken some measure or penned an executive order, instructing agencies how to alter their procedures of regulatory impact analysis, or more specifically cost-benefit analysis (Kerwin and Furlong 2019). Congress and the White House have also sought means by which to make rulemaking more flexible and accommodating to affected interests, such as negotiated rulemaking.

We focus on traditional, "notice and comment" rulemaking, also often known as "informal rulemaking" when referring to rules that were not specifically requested by Congress. Notice and comment involves two stages as laid out by the APA. First, the agency gathers information, does preliminary analysis and announces a "Notice of Proposed Rulemaking" (NPRM). Subsequent to that, the agency opens the rule for public comment for some finite period of time, considers the feedback it has received and then issues a final rule. The quantity of comments from organized interests during the notice and comment process, as well as the level of responsiveness that the EPA and other agencies demonstrate towards these comments are both important questions and the focus of much scholarly debate.

We explore these issues in detail, while accounting for how regulatory and policymaking institutions have transformed over time, thereby affecting the rulemaking process. In the first section, we describe the nature of environmental rulemaking - and environmental policymaking more generally_as highly contested between competing

\footnotetext{
${ }^{1}$ Other agencies are considered as well, such as the Department of Interior, and some of its constitutive organisations, but the focus for most of the chapter is on the EPA.
} 
organized interests and politicians that seek to influence bureaucrats with policymaking expertise. Second, we discuss the dynamics of accountability, how the different principals compete to influence agencies like the EPA and how those agencies respond. We look closely at the role of regulatory impact analysis and how political decisions over seeminly technocratic matters can significantly affect environmental policy outcomes. Third, in addition to examining the role of courts in rulemaking, we analyse regulatory reforms, such as regulatory negotiations. Finally, we conclude with thoughts about new directions in research on environmental rulemaking and policy more broadly.

\section{The Political Nature of Environmental Rulemaking}

Before analysing environmental rulemaking in the U.S. federal bureaucracy, it is necessary to understand the dynamics of accountability in environmental politics. Clean and poison-free air, land and water bring benefits to everyone, but the costs of regulation are typically borne by business. Wilson has argued that when the benefits of regulation are dispersed, but the costs are concentrated, it produces "entrepreneurial politics" (1980), whereby organized interests, such as the Sierra Club and the Natural Resource Defense Council (NRDC), must overcome collective action problems of ordinary citizens. The ability of the entrepreneur to mobilize and shape the debate is particularly crucial, given that many businesses and their lobbyists are better organized and suffer lower information and resource costs (Stigler 1971). The contestation associated with entrepreneurial politics makes environmental politics an issue of high salience, as elected politicians want to maintain control over the issue (Gormley 1986; Ringquist, Worsham and Eisner 2003), but the complexity of environmental policy requires experts from a number of professions to help determine how much pollution is permissible under a range of different circumstances.

The issues of salience and complexity influence how authority is delegated to bureaucratic agencies. Principals (Congress and the President) must delegate authority to the 
expert agents (bureaucratic agencies) to implement environmental law and policy, but they must also hold these agents accountable. McCubbins, Noll and Weingast (McNollgast; 1987, 1989) argue that Congress "stacks the deck" in bureaucratic agencies towards particular constituents by "hard wiring" agencies with particular administrative procedures that dictate that agencies, for example, perform cost-benefit analysis (CBA), consult with particular organized interests or respond to fire alarm oversight (see McCubbins and Schwartz 1984). ${ }^{2}$

The true picture that emerges from these conditions of highly salient and complex policymaking is a bit messier than what is envisioned by McNollgast. The unrealistic expectations of what the EPA can accomplish in a relatively short period of time are often reflected in Congress's administrative requirements. Environmental groups want stringent rules, businesses want some certainty in the regulatory landscape, both groups therefore put a premium on rapid decision making, but given the EPA's need to balance, science, economics and politics, expedited rulemakings are rarely on offer. The high stakes involved makes rules all the more contested, which results in ever more congressional prescriptions and requirements heaped upon EPA policymaking.

The salient and complex nature of environmental policymaking that drives this highly contested state of affairs also helps to produce many of the accountability dynamics that we discuss in the rest of the chapter. Regulators at the EPA and other agencies must balance numerous competing demands while producing sufficiently competent analyses that justify their decisions. At the same time, Congress, the President, the courts and organized interests all jockey for influence through executive orders, revisions to regulatory impact analysis, litigation, and administrative and procedural reforms.

\footnotetext{
${ }^{2}$ For a more complete discussion of delegation, see for example, Bawn (1995), Epstein and O'Halloran (1999), Ringquist, Worsham and Eisner (2003)
} 


\section{Accountability in Environmental Rulemaking}

How responsive are agencies to comments presented to them in the notice and comment process? Although much of the heavy lifting of regulatory analysis takes place before agencies issue an NPRM, much research has focused on the questions of participation and responsiveness in rulemaking. Business as a whole is a well-organized set of interests, bearing many of the costs of environmental regulation. Consequently, it would seem that organized business interests have both the ability and strong incentives to participate as much as possible in the rulemaking process (see e.g. Golden 1998). Much of the rulemaking literature has indeed borne out this hypothesis.

Studies have revealed that business as an organized interest tends to contribute a large proportion of comments submitted during the notice and comment period (Croley 1998;

Golden 1998; Furlong and Kerwin 2005; Yackee and Yackee 2006). But what influence does this disproportionate participation have on the rulemaking process? Yackee codes nearly 1,500 comments on forty federal rules and finds that organized interests do have influence (2006); in a parallel study, published in the same year, she and co-author Yackee find a more specific influence of business brought to bear on rulemaking (Yackee and Yackee 2006). In follow-up studies, Yackee and co-authors find that the more business competes with opposing commenters on given rules, the more its influence wanes (Yackee 2014; McKay and Yackee 2007). These studies highlight the important role of business, but also the importance of competition for business, if its influence is it to be mitigated.

Much of the aforementioned literature focuses on the second stage of notice-andcomment rulemaking, whereby agencies solicit comments on rules published in the federal register, as part of the NPRM phase. However, recent studies have also been careful to address the influence of different organizations in the very first phase of rulemaking, when agency officials craft the rule, utilizing stakeholder input (Cook and Rinfret 2013). A theme 
that emerges from this literature is that agency officials are often reliant on stakeholder input during this first rulemaking stage at the U.S. Fish and Wildlife Service (Cook and Rinfret 2013), the EPA (Rinfret 2011) and the Department of Transportation (Naughton et al. 2009). Naughton et al. find that this effect is particularly robust for "early bird" commenters, who have more success in bringing influence to bear in the first stage of rulemaking.

\section{Regulatory Impact Analysis and Political Control}

Organized interest influence over rulemaking processes does not occur in a vacuum. A wealth of evidence demonstrates political influence, as the executive and legislative branches of government vie for control, utilizing a multitude of legal and administrative tools (e.g. Carpenter 1996; Lewis 2008; Wood and Waterman 1994; Whitford 2005). In rulemaking, a rich literature has developed around the influence that Congress and the President seek to wield, by modifying the procedures of regulatory impact analysis, by writing new executive orders and by passing legislation. Adjusting the requirements of impact analysis, and specifically cost-benefit analysis (CBA), can raise or lower the costs of regulation for businesses, depending on the nature of the administrative change and on the presidential administration bringing the change.

$\mathrm{CBA}$ is a form of regulatory impact analysis that is designed to ensure that regulators choose the rulemaking option that maximizes benefits over costs. Shifts in the measurement of costs and benefits partially determine which rules become law and which never see the light of day. Early fights over CBA structure were largely conducted along partisan lines; proposals for clean air and water legislation mandated that agencies should ignore the compliance cost to businesses (Moe 1989), while President Nixon created a Quality of Life Committee designed to ensure that both costs and benefits were taken account in new rules (Layzer 2012; Tozzi 2011). 
The institutional embodiment of CBA varied for the next several years, but it became permanently part of the rulemaking landscape with Reagan's Executive Order (EO) 12291. EO 12291 emphasized the need for benefits to exceed costs and also required that CBA be completed for all rules estimated to generate impact of at least $\$ 100$ million (Kerwin 2003). While E.O. 12291 was ideologically conservative in its emphasis on regulatory costs, it created the foundation for similar, future EOs until President Clinton changed the scope of 12291. E.O. 12886 continued to enshrine the principle of CBA, but it loosened the requirements for rules to be reviewed by the Office of Information and Regulatory Affairs (OIRA), an important sub-division of OMB (the Office of Management and Budget).

The use of CBA in rulemaking has generally been applauded as a positive development that forces regulators to think carefully about costs and benefits in different policy options (Hahn and Hird 1991; Hahn and Litan 2005; Hahn and Sunstein 2002). To this end, there has been a persistent drumbeat advocating for greater use of CBA in government, coming from both academics and practitioners. At the same time, scholars have produced a number of studies that capably evaluate the effects of environmental regulations, as a parallel to CBA (e.g. Ringquist 1993; Greenstone 2002). However, other scholars have resisted utilizing strict forms of CBA, arguing that its assumptions are unrealistic. The most common criticism of CBA, particularly with regard to environmental rules, is that the measurement of benefits does not lend itself to simple calculations. Some benefits may be difficult to quantify; others may be difficult to average across smaller populations and others just may lack the data to give an accurate picture.

Valuing human life and gauging the duration of regulatory benefits are two of the most contentious areas of benefit measurement. The value of a statistical life-what earnings people are willing to forego in order to avoid particular risks— — has been researched extensively (e.g. Viscusi and Aldy 2002), but debates remain about how to value human life, 
simply because higher values mean higher benefits which result in potentially more costly regulations for business. Agencies under President Obama raised the value of a statistical life because numbers had remained stagnant under President Bush, with agencies often failing to adjust figures for inflation (Appelbaum 2011). The second controversial dimension - the setting of a discount rate-determines how valuable future regulatory benefits are perceived relative to the present. Setting a low rate suggests that benefits will last far into the future, while a high discount rate suggests sharply diminishing returns over time. Again, there are clear distributive implications here and the most prominent example comes from the UK. Economist Nicholas Stern published a controversial review of the predicted effects of climate change in 2006, a study in which he used a discount rate of close to zero, which had the effect of augmenting the value of climate change policies in the longer run (Beckerman and Hepburn 2007).

Thomas McGarity presents one of the broadest and most articulate criticisms of CBA, in the context of complex social regulatory policy, such as environmental regulation (1991). McGarity's discussion represents a proxy battle between the schools of rational choice and bounded rationality, as he argues that the information and analytical requirements embedded within CBA are impractical and inconsistent with the manner in which bureaucrats actually behave. He argues, not only that benefits are difficult to measure, but that much of the time data will be incomplete; it will be challenging to rank order specific policy values; the list of policy alternatives is unlikely to be comprehensive, as some will be non-starters, and finally costs may change as a result of compliance with new rules. Just as Herbert Simon's boundedly rational administrator strove to achieve satisficing, threshold goals (1947), McGarity's regulators strive to produce rules that satisfy some policy objectives, but will also survive legal and political challenges. 
McGarity's concerns regarding the data and analysis requirements of CBA are particularly pertinent, when one considers the complexity of environmental rulemaking. Sound scientific information should inform new rules, and if environmental protection was a low-salience issue, then science could be the pre-dominant determinant of new rule content. However, environmental rules matter greatly to citizens, organized interests, businesses, and elected politicians. Scientific considerations in rulemaking are inevitably balanced against economic and political considerations (Rosenbaum 2006; Whitford 2014). Congress and successive presidents have spent considerable resources trying to influence the procedures by which rule content is decided.

Given the complexity surrounding many CBA exercises, many scholars have argued that CBA is used more to justify decisions after the fact, rather than inform decision making beforehand (Carrigan and Shapiro 2017; Wagner 2009). Consistent with this reasoning, Raso finds that environmental rulemakers are likely to avoid rulemaking altogether if they believe a new policy is not likely to be challenged in court (2015). Such a lack of engagement with rulemaking may also be the result of increasingly complex information emanating from business sources. Wagner argues that businesses increasingly seek to overwhelm regulators with highly technical information, in a process she calls "information capture" (2010). Wagner's theory of information capture is also consistent with business efforts to alter scientific standards in rulemaking along the way. In 2004, the Washington Post reported that the little noticed Data Quality Act had allowed businesses to submit analyses in rulemaking that effectively manufactured doubt regarding established scientific findings (Weiss 2004).

One way in which the executive branch has consistently tried to influence rulemaking is through the use of EOs, which dictate the way in which regulatory impact analysis and CBA should be conducted. Perhaps the best example of an EO that attempts to steer policymaking while generating very uncertain effects is EO 12898, passed by President 
Clinton in February, 1994. As the first federal attempt to address socioeconomic inequities in pollution's distribution, the order requires that agencies account for the impact that a new rule will have on environmental inequities. Uncertainty remains around definitions, as well as some of the evidence linking variations in pollution to specific inequities in health (Banzhaf 2011; Noonan 2015; Shadbegian and Wolverton 2015). Such uncertainty produces more risk averse behaviour on the part of rulemakers, as they claim that new rules will not exacerbate environmental inequities, rather than promoting the positive effects (Banzhaf 2011; Provost and Gerber 2019).

\section{Courts and the EPA}

Another political master that the EPA has to face is the American court system, specifically the federal courts. EPA rules have frequently been subject to judicial challenge, often by business for being too stringent or from environmental groups for not being stringent enough. Judges typically do not possess the expertise to decide on rule content, but this has not stopped them from rendering decisions that would change the substance of rules and the the rulemaking process (e.g. Melnick 1983; O’Leary and Straussman 1993). The APA requires that agencies not make rules in an "arbitrary and capricious" fashion, but it is difficult to separate the substance of a rule from the manner in which it was formulated. The 1971 decision of Citizens to Preserve Overton Park vs. Golpe brought about the "hard look" doctrine (Cooper 2004; Kerwin 2003) and consequently, "judicial decisions were rendered that had the effect of altering rulemaking procedure" (Kerwin 2003: 248).

The Supreme Court laid the groundwork for more agency latitude, when it reversed the D.C. Circuit Appellate Court in upholding a Nuclear Regulatory Commission decision in the 1978 case of Vermont Yankee vs. Power Corporation vs. Natural Resources Defense Council. Judicial deference to regulatory agencies was further reinforced and expanded in 
the 1984 decision of Chevron vs. Natural Resources Defense Council. Scholars have argued that Chevron works at odds with the 1983 decision of Motor Vehicle Manufactuers Association vs. State Farm Mutual Automobile Insurance, which reversed the National Highway Traffic Safety Association's decision to repeal an already existing rule (Cooper 2005; Kerwin 2003).

Kerwin looks to the type of agencies that are likely to endure high levels of litigation (2003). Not surprisingly, he argues that "social regulation" agencies, protective of the environment and public health, are more likely to experience litigation because of the "magnitude of negative effects" generated by new rules (Kerwin 2003: 251). These rules touch upon whole sectors of the economy, while at the same time stimulating polarizing opinions on both sides of the debate. Such conditions also exemplify, however, the competitive nature of environmental rulemaking, which may slow down the policymaking process, but also mitigate the influence of business.

Regardless of this conflict, Chevron deference to agency decision making still holds. Since 1984, businesses have grown to significantly dislike Chevron and other precedentsetting decisions that mandate judicial deference to agency decision making, such as the 1997 decision of Auer vs. Robbins (Weiss 2018). Such dislike arises from the perception that agencies frequently promulgate unreasonable rules which Courts are powerless to strike down because of the Chevron binds that tie the hands of judges. However, Supreme Court judges have reversed agency action, most notably in Massachusetts vs. EPA, where the Court found lacking the agency's rationale for not regulating carbon dioxide emissions. Freeman and Vermuele argue that the Court overruled the EPA in this case because "of the sense that executive expertise had been subordinated to politics" (2007: 52). Moncrieff, on the other hand, argues that the EPA made the correct administrative choice not to regulate and that the Court should have embraced Chevron deference to validate that decision (2008). Cases like 
this demonstrate the difficulties in separating process vs. substance in judging regulatory rules. In 2019, the Court reluctantly upheld Auer deference in Kisor vs. Wilkie, but the willingness of the conservative wing of the Court to strike down such deference indicates there may yet be a newly significant role for the judiciary in environmental regulation.

\section{Rulemaking "Ossification" and Reform}

It is logical to think that the administrative burdens, shifting and expanding requirements could affect the rulemaking output of most regulatory agencies. This is the argument that additional requirements have slowly "ossified" the rulemaking process (Mashaw 1994; McGarity 1992; Pierce 1995; Seidenfeld 1997). Carrigan and Shapiro present evidence that impact analyses have grown longer over time, specifically by, on average nearly 100,000 words between 2000 and 2012 (2017). Increased word length in impact analyses may be the result of additional administrative requirements and may also decrease the pace of rulemaking, although neither of these claims can be verified by their evidence alone.

Because a number of these studies did not actually test the ossification hypothesis, Yackee and Yackee set out to correct this oversight. They don't find strong support for the ossification hypothesis in two separate studies $(2010,2012)$ and even find that, procedural requirements can speed up rulemaking (2010). Consistent with these findings, Raso finds that agencies frequently avoid rulemaking altogether, if the threat of litigation against such practices is low (2015). Such a practice suggests that regulators may be avoiding precisely the rulemaking situations that would require the most time. However, Pierce takes issue with the methodology employed by Yackee and Yackee and argues that ossification is still a problem (2012). Additionally, time spent crafting new rules may not be the only indicator of ossification; Carrigan and Shapiro, in their argument for simpler cost-benefit analyses, find 
that impact analyses have increased considerably in word length, at least between 2000 and 2012 (2017). Rinfret and Cook find that ossification does play a role in National Park Service rulemaking, but their interview data reveals that greater stakeholder engagement can lessen this impact (2017).

\section{Negotiated Rulemaking}

Even if some scholarly evidence disproves the ossification hypothesis of rulemaking, policymakers and academics in the early 1980s agreed that it was happening. The response was the advocacy of a rulemaking approach, based on forging consensus beforehand, in an effort to reduce litigation and speed up the overall process. This approach was known as negotiated rulemaking or regulatory negotiations (reg-neg). Reg-neg, which was designed to supplement the notice-and-comment rulemaking process, was founded on principles of arbitration whereby the relevant interests were identified by the agency in advance and brought around a table in order to enhance the participation of all affected constituents and get better information on how to minimize conflict.

Philip Harter was an early proponent of reg-neg, explaining in extensive detail how reg-neg could bring a more informal and efficient approach to a heavily formalized rulemaking process. (1982). Fiorino echoes Harter's positive assessment of reg-neg: "By aggregating interests in the form of knowledgeable parties with the resources and incentives to participate, negotiation can produce workable, pragmatic regulations that stand a better than usual chance of being implemented" (1988: 770). Weber and Khademian too emphasize the benefits of negotiating at the table before rulemaking, as "sharing information creates opportunities...to discover more numerous and innovative solutions...that would otherwise be beyond their reach" (1997: 770). Perritt, however, points out that reg-neg should target programs whose benefits and costs are heavily concentrated, as this makes it easier to 
mobilize interests (1986). Congress formally endorsed reg-neg as a regulatory reform by passing the Negotiated Rulemaking Act of 1990 and reauthorizing it in 1996.

Other assessments of reg-neg have been more mixed. Susan Rose-Ackerman has questioned the conceptual foundations of reg-neg, arguing that it does little to produce the right incentives for those actors involved (1994). Empirical evidence at best presents a mixed picture. Kerwin and Furlong, compare four reg-neg rules against a small sample of conventional rulemakings, and reveal significant time savings with reg neg (1992). However, Coglianese finds in his own more comprehensive analysis that reg-neg affords no such time savings and reg-neg rules are not necessarily subject to less litigation.

Weber and Khademian also paint a more mixed picture of reg-neg outcomes (1997). Utilizing an EPA case study on reformulated gasoline from the G.H.W. Bush Administration, they find that reg-neg enhanced the consensual nature of the process and helped make compliance with the final rule more feasible. However, they also highlight that the dispute resolution techniques embedded in the reg-neg process may represent a subtle form of political control entrenchment of economic interests at the expense of consumer priorities-a concern also shared by Funk (1997). Weber and Khademian also argue that a lack of credible commitment can torpedo reg-neg rules, as they can be legally challenged after publication and there are no formal mechanisms for preventing Congress or the President from interfering in the process. The doubts about reg-neg's performance appeared to catch up with it over time, as it largely stopped being used within the EPA by the early 2000s (Lubbers 2008). However, Rinfret and Cook reveal that the EPA is making the most of the consultative elements of reg-neg and consulting with a wide range of groups in a process known as "reg neg lite" or "shuttle diplomacy" (2014).

The quest for regulatory efficiency produces in most administrations a drive to reduce red tape, often with EOs or requirements to jettison some number of existing rules. 
Reductions in red tape have often been sought through adjustments to the CBA process (e.g. Presidents Bush and Obama both sought to adjust EO 12866, through 13422 and 13563, respectively). President Trump, in early 2017, made a more explicit attempt to reduce the stockpile of rules with a new "one in, two out" rule, partly based on the 2011 UK government policy of the same name (Gayer, Litan and Wallach 2017). While this policy offers some flexibility in its interpretation, it is still a difficult one to implement: rulemakers cannot just eliminate rules unilaterally, rather they must go through the same notice-and-comment process to get rid of a rule, as an agency would to produce a rule. This process may be met with disagreeable comments, or litigation that stops the elimination of the rule. Where such procedural requirements are in place to eliminate regulations, it can be more difficult to identify rules that are pointless "or just plain dumb" to quote President Obama (McCardle and Nelson 2011). Most rules serve someone's interest and as long as the process to eliminate rules is transparent and formalized, it will be more difficult to eliminate them-and will make it more difficult to judge such "one in, two out" sorts of policies to be a success.

\section{Rulemaking and Federalism}

If reg-neg failed to speed up the process of rulemaking, then other developments in federalism would soon be responsible for challenging the long-term survival of new rules. State attorneys general (state AGs) had become a potent regulatory force in American politics by the early 2000 s, by banding together and bringing multi-state lawsuits against private companies (Clayton 1994; Mather 2003; Nolette 2015; Provost 2003), but during the George W. Bush Administration, lawsuits against the federal government began to rise as well.

In 2003, the Bush EPA sought to make high-profile rule changes to a program under the Clean Air Act entitled "New Source Review" (NSR) whereby power plants, when making upgrades to the machinery and hardware of the plant, were also legally required to upgrade 
the pollution abatement equipment within the plant (Barcott 2004). A key question within the NSR regulations was where the threshold should lie between "routine maintenance" and more costly upgrades that required anti-pollution maintenance. The Bush EPA's settled answer of 20 percent of the plant's value far exceeded industry's requests, and was challenged by 9 Democratic AGs, before being partially thrown out in Court (Barcott 2004). But the more significant and long-term change would be state AG willingness to take on EPA rule changes.

A second front between Democratic AGs and the Bush EPA opened up in 2003 as well, as the question of how to regulate carbon dioxide emissions took center stage. After Bush EPA officials argued that the Clean Air Act did not provide the EPA with the legal authority to regulate carbon dioxide emissions (Lee 2003), fourteen Democratic AGs brought lawsuits against the EPA, asking that the EPA regulate $\mathrm{CO} 2$ emissions from automobiles. The case reached the Supreme Court (Massachusetts vs. EPA), where a narrow 5-4 majority ruled that the EPA's refusal to regulate $\mathrm{CO} 2$ emissions amounted to a use of power that was "arbitrary, capricious or otherwise not in accordance with the law" under the APA. Thus, the Supreme Court's decision, in effect, amounted to a rebuke of the EPA for not promulgating rules regarding $\mathrm{CO} 2$ emissions.

\section{FIGURE 1 HERE}

Lawsuits brought by Democratic AGs against the Bush Administration EPA commenced a new era of partisan polarization whereby state AGs of one party challenged new rules produced by the presidency of the other party. As Figure $1^{3}$ illustrates, this trend

\footnotetext{
${ }^{3}$ Most of the actions in this figure represent legal actions against newly promulgated rules, although in some cases, they are filings of amicus curiae or as intervenors in other lawsuits. Data come from the "Attorney General Multistate Lawsuits and Settlements Database, 1980-2013” (Nolette 2015).
} 
largely began in 2003, when Democratic AGs brought a then-record number of 10 environmental lawsuits against the Bush Administration. Republican AGs countered with 10 in 2010, in attempts to roll back the Obama Administration's ambitious environmental policies. Major Democratic losses in the 2010 and 2014 midterm elections had the twin effects of taking away the Administration's Democratic majority in Congress, while also boosting the number of Republican AGs. Consequently, President Obama had to rely on a unitary, administrative strategy of environmental rulemaking, to which Republican AGs responded with 9 lawsuits in 2015. Finally, as the figure indicates, polarized environmental policy has not subsided at all during the Trump Administration. Trump's policy goals of taking the U.S. out of the Paris Climate Accord, boosting the coal industry, while killing off Obama’s 2015 Clean Power Plan, predictably generated a significant backlash from Democratic AGs, who brought 17 lawsuits against new Trump initiatives in 2017 alone.

\section{Discussion and Conclusion}

In this chapter, we have described the highly contested nature of environmental rulemaking and how it affects the dynamics of accountability. Some scholars have argued that environmental regualtion has become less adversarial over time, as one of several key shifts in environmental policymaking (e.g. Fiorino 2009). However, there are a number of reasons to believe that environmental regulation will continue to be a contested, even polarizing, topic in the United States. First, while surveys tend to show high levels of support for environmental policies overall, these are increasingly divided along party lines, particularly with respect to climate change (e.g. Dunlap et al. 2016). Second, as we showed in the last section, this partisan polarization has created new venues of litigation in policy making at the state level, as partisan groups of state AGs target EPA rules, ensuring one more obstacle to rule survival. Third, agitation in the business community for the courts to revise 
standards of judicial deference to agencies may create a new policymaking role for the courts in the not so distant future.

What are the potential consequences to a continued pattern of highly contested rulemaking? As Yackee (2013) shows, when there is more competition in rulemaking, the potential for outsized business influence — even regulatory capture — tends to diminish. On the other hand, such contestation can slow down the rulemaking process, increase the chances of litigation and lead to demands for more informal modes of policymaking, such as reg-neg. While reg-neg's death in administrative law has been well documented (Lubbers 2008), aspects of its existence live on, through informal consultations, thereby bringing greater representativeness to the rulemaking process (Rinfret and Cook 2014). "Reg neg lite", as Rinfret and Cook (2014) refer to it, appears to represent a simpler and more informal method of creating rules. On a parallel track, Carrigan and Shapiro's (2017) call for simplied CBA will surely be received sympathetically by many rulemakers, but the high stakes involved make such proposals less likely.

Looking more broadly at environmental policy, the challenges of climate action suggest a need for greater coordination. While the advent of environmental management systems and corporate social responsibility in the environment make it easier for business to agree to new environmental rules, climate change and changes in energy policy increase the coordination challenges and therefore, the tasks of rulemakers as well. Given that climate change is affected by transportation, manufacturing, energy, agriculture and a number of other industries, it would appear that agencies need to find ways of collaborating in their policy and rulemaking to address these problems together. Additionally, transitions towards clean energy production in many parts of the U.S. create new jobs, but also displace old ones in fossil fuel industries. This as well suggests the need for greater coordination in federal environmental and energy policymaking. However, given the domains, procedures and 
audiences of each agency, not to mention the autonomous actions of states and localities, it remains to be seen whether agencies can successfully join up their efforts in meaningful ways. As the U.S. continues to address climate change, examining these coordination challenges in a federalist system should be a research priority. 


\section{References}

Antonio, Robert J. and Robert J. Brulle. 2011. "The Unbearable Lightness of Politics: Climate Change Denial and Political Polarization," The Sociological Quarterly, 52 (2): 195202.

Appelbaum, Binyamin. 2011. "As U.S. Agencies Put More Value on Life, Businesses Fret," New York Times, 16 Febuary.

Bawn, Kathleen. 1995. "Political Control Versus Agency Expertise: Congressional Choices about Administrative Procedures,” American Political Science Review, 89: 62-73.

Banzhaf, H. Spencer. 2011-12. "Regulatory Impact Analyses of Environmental Justice Effects," Journal of Land Use, 27: 1-31.

Barcott, Bruce. 2004. "Changing All the Rules,” New York Times, 4 April: 38.

Beckerman, Wilfred and Cameron Hepburn. 2007. "Ethics of the Discount Rate in the Stern Review on the Economics of Climate Change," World Economics, 8 (January-February): 187-210.

Carpenter, Daniel. 1996. "Adaptive Signal Processing, Hierarchy and Budget Control in Federal Regulation," American Political Science Review, 2: 283-302.

Carrigan, Christopher and Stuart Shapiro. 2017. "What's Wrong with the Back of the Envelope? A Call for Simple (and Timely) Cost Benefit Analysis," Regulation and Governance, 11: 203-212.

Clayton, Cornell. 1994. "Law, Politics and the New Federalism: State Attorneys General as National Policymakers," The Review of Politics, 56 (Summer): 525-553.

Coglianese, Gary. 1997. “Assessing Consensus: The Promise and Performance of Negotiated Rulemaking,” Duke Law Journal, 46 (April): 1255-1350.

Cooper, Philip J. 2004. Cases on Public Law and Public Administration. Wadsworth Publishing.

Cook, Jeffrey and Sara Rinfret. 2013. "A Revised Look: EPA Rulemaking Processes," Journal of Environmental Studies and Sciences, 3 (September): 279-289.

Croley, Steve. 1998. "Theories of Regulation: Incorporating the Administrative Process, Columbia Law Review," 98: 1-168

Dunlap, Riley E., Aaron M. McCright and Jerrod H. Yarosh. 2016. "The Political Divide on Climate Change: Partisan Polarization Widens in the U.S.," Environment: Science and Policy for Sustainable Development, 58 (5): 4-23.

Epstein, David and Sharyn O'Halloran. 1999. Delegating Powers: A Transaction Cost Approach to Policy Making Under Separate Powers. New York: Cambridge University Press.

Fiorino, Daniel J. 1988. "Regulatory Negotiation as a Policy Process," Public Administration Review, 48 (July): 764-772. 
Fiorino, Daniel J. 2009. "Regulating for the Future: A New Approach for Environmental Governance," in Towards Sustainable Communities: Transition and Transformations in Environmental Policy, $2^{\text {nd }}$ edition, eds. Daniel A. Mazmanian and Michael E. Kraft. Cambridge: MIT Press.

Freeman, Jody and Adrian Vermuele. 2007. "Massachusetts vs. EPA: from Politics to Expertise," The Supreme Court Review, 2007: 51-110.

Funk, William. 1997. "Bargaining Toward the new Millennium: Regulatory Negotiation and the Subversion of the Public Interest" Duke Law Journal, 46 (April): 1351-88.

Furlong, Scott and Cornelius Kerwin. 2005. "Interest Group Participation in Rule Making: A Decade of Change," Journal of Public Administration Research and Theory, 15(3): 353370.

Gayer, Ted, Robert Litan and Philip Wallach. 2017. "Evaluating the Trump Administration's Regulatory Reform Program," The Brookings Institution, October.

Golden, Marissa. 1998. "Interest groups in the rule-making process: Who participates? Whose Voices get heard?" Journal of Public Administration Research and Theory 8: 245-70.

Gormley Jr., William T. 1986. "Regulatory Issue Networks in A Federal System,” Polity, 18 (Summer): 595-620.

Greenstone, Michael. 2002. “The Impacts of Environmental Regulations on Industrial Activity: Evidence from the 1970 and1977 Clean Air Act Amendments and the Census of Manufactures," Journal of Political Economy, 110 (6): 1175-1219.

Hahn, Robert and John Hird. 1991. "The Costs and Benefits of Regulation: Review and Synthesis," Yale Journal on Regulation, 8 (1): 233-278.

Hahn, Robert and Robert Litan. 2005. "Counting Regulatory Costs and Benefits: Lessons for the U.S. and Europe," Journal of International Economic Law, 8(2): 473-508.

Hahn, Robert and Cass Sunstein. 2002. "A New Executive Order for Improving Federal Regulation-Deeper and Wider Cost Benefit Analysis," University of Pennsylvania Law Review, 150 (5): 1489-1552.

Harter, Philip. 1982. "Negotiating Regulations: A Cure for Malaise" Georgetown Law Journal, 71: 1-113.

Kerwin, Cornelius M. 2003. Rulemaking: How Government Agencies Write Law and Make Policy. $3^{\text {rd }}$ edition. Washington: Congressional Quarterly Press.

Kerwin, Cornelius M. and Scott Furlong. 1992. Time and Rulemaking: An Empirical Test of Theory," Journal of Public Administration Research and Theory, 2 (April): 113-138.

Kerwin, Cornelius M. and Scott Furlong. 2019. Rulemaking: How Government Agencies Write Law and Make Policy. $5^{\text {th }}$ edition. Washington: Congressional Quarterly Press.

Layzer, Judith. 2012. Open for Business: Conservatives' Opposition to Environmental Regulation. Cambridge: MIT Press. 
Lee, Jennifer. 2003. “E.P.A. Says It Lacks Some Power to Regulate Some Gases,” New York Times, 17 August: A17.

Lewis, David E. 2008. The Politics of Presidential Appointments: Political Control and Bureaucratic Performance. Princeton: Princeton University Press.

Lubbers, Jeffrey S. 2008. "Achieving Policymaking Consensus: the (Unfortunate) Waning of Negotiated Rulemaking," Texas Law Review, 49: 987-1017.

Mashaw, Jerry. 1994. "Improving the Environment of Agency Rule-Making: An essay on Management, Games, and Accountability," Law and Contemporary Problems 57:185-257.

Mather, Lynn. 2003. "The Politics of Litigation by State Attorneys General: Introduction to Mini-Symposium," Law and Policy, 25 (October): 425-428.

McArdle, John and Gabriel Nelson. 2011. "Obama Issues Executive Order to Cut Red Tape,” New York Times, (Accessed July 18, 2019:

https://archive.nytimes.com/www.nytimes.com/gwire/2011/01/18/18greenwire-obamaissues-executive-order-to-cut-red-tape-93114.html)

McCubbins, Mathew, Roger Noll, and Barry Weingast. 1987. "Administrative Procedures as Instruments of Political Control.” Journal of Law, Economics, and Organization 3:243-277.

McCubbins, Mathew, Roger Noll, and Barry Weingast. 1989. "Structure and Process, Politics and Policy: Administrative Arrangements and Political Control of Agencies." Virginia Law Review 75: 431-482.

McCubbins, Matthew and Thomas Schwartz. 1984. "Congressional Oversight Overlooked: Police Patrols versus Fire Alarms.” American Journal of Political Science 28 (1): 165-179.

McGarity, Thomas O. 1991. Reinventing Rationality: The Role of Regulatory Analysis in the Federal Bureaucracy. Cambridge: Cambridge University Press.

McGarity, Thomas. 1992. "Some Thoughts on De-Ossifying the Rulemaking Process" Duke Law Journal, 41: 1385-462.

McKay, Amy and Susan Webb Yackee. 2007. "Interest Group Competition on Federal Agency Rules," American Politics Research, 35 (May): 336-357.

Melnick, R. Shep. 1983. Regulation and the Courts: the Case of the Clean Air Act. Washington D.C.: Brookings Institute Press.

Moe, Terry. 1989. "The Politics of Bureaucratic Structure.” In Can the Government Govern? ed. John E. Chubb and Paul E. Peterson. Washington, D.C.: The Brookings Institution.

Moncrieff, Abigail. 2008. "Reincarnating the 'Major Questions' Exception to Chevron Deference as a Doctrine of Noninterference (or Why Massachusetts vs. EPA Got it Wrong)," Administrative Law Review, 60 (Summer): 593-646. 
Naughton, Keith, Celeste Schmid, Susan Webb Yackee and Xueyong Zhan. 2009.

"Understanding Commenter Influence During Agency Rule Development," Journal of Policy Analysis and Management, 28 (2): 258-277.

Nolette, Paul. 2015. Federalism on Trial: State Attorneys General and National Policymaking in Contemporary America. Lawrence, KS: University of Kansas Press.

Nolette, Paul and Colin Provost. 2018. "Change and Continuity in the Role of State Attorneys General in the Obama and Trump Administrations," Publius: the Journal of Federalism 48 (3): 469-494.

Noonan, Douglas. 2015. “Assessing the EPA's Experience with Equity in Standard Setting," in Failed Promises: Evaluating the Federal Government's Response to Environmental Justice, ed. David Konisky. Cambridge: MIT Press.

O'Leary, Rosemary and Jeffrey D. Straussman. 1993. "The Impact of Courts on Public Management, " in Public Management: State of the Art, ed. Barry Bozeman. San Francisco: Jossey-Boss.

Perritt, Henry H. Jr. 1986. "Negotiated Rulemaking in Practice" Journal of Policy Analysis and Management, 5: 482-495.

Pierce Jr., Richard J. 1995. "Seven Ways to Deossify Agency Rulemaking," Administrative Law Review, 47: 59-95.

Pierce Jr., Richard J. 2012. "Rulemaking Ossification is Real: A Response to Testing the Ossification Thesis," George Washington Law Review 80 (5): 1493-1503.

Provost, Colin. 2003. "State Attorneys General, Entrepreneurship and Consumer Protection in the New Federalism," Publius: the Journal of Federalism, 33 (Spring): 37-53.

Provost, Colin and Brian J. Gerber. 2019. "Political Control and Policymaking Uncertainty in Executive Orders: The Implementation of Environmental Justice Policy," Journal of Public Policy 39 (2): 329-358..

Raso, Connor. 2015. "Agency Avoidance of Rulemaking Procedures," Administrative Law Review, 67 (1): 65-132.

Rinfret, Sara. 2011. "Frames of Influence: U.S. Environmental Rulemaking Case Studies," Review of Policy Research, 28 (3): 231-246.

Rinfret, Sara and Jeff Cook. 2014. "Environmental Policy Can Happen: Shuttle Diplomacy and the Reality of Reg Neg Lite," Environmental Policy and Governance, 24: 122-133.

Rinfret, Sara and Jeff Cook. 2017. "The NPS and Ossification: Does it Still Exist?" International Journal of Public Administration, 40:2, 138-149.

Ringquist, Evan. 1993. "Does Regulation Matter? Evaluating the Effects of State Air Pollution Control Programs," Journal of Politics 55 (November): 1022-1045. 
Ringquist, Evan J., Jeff Worsham and Marc Allen Eisner. "Salience, Complexity and Legislation Direction of Regulatory Bureaucracies," Journal of Public Administration Research and Theory, 13 (April): 141-164.

Rose-Ackerman, Susan. 1994. "Consensus Versus Incentives: A Skeptical Look at Regulatory Negotiation” Duke Law Journal, 43 (April): 1206-1220.

Rosenbaum, Walter A. 2006. "Improving Environmental Regulation at the EPA: The Challenge in Balancing Politics, Policy and Science," in Environmental Policy: New Directions for the Twenty-First Century, ed. Norman J. Vig and Michael E. Kraft. Washington D.C.: Congressional Quarterly Press.

Seidenfeld, Mark. 1997. "Demystifying Deossification: Rethinking Recent Proposals to Modify Judicial Review of Notice and Comment Rulemaking," Texas Law Review, 75: 483524.

Shadbegian, Ronald and Ann Wolverton. 2015. "Evaluating Environmental Justice: Analytic Lessons from the Academic Literature and in Practice," in Failed Promises: Evaluating the Federal Government's Response to Environmental Justice, ed. David Konisky. Cambridge: MIT Press.

Simon, Herber. 1947. Administrative Behavior: A Study of Decision Making Processes in Adminstrative Organizations. New York: Free Press.

Stigler, George. 1971. "The Theory of Economic Regulation," Bell Journal of Economics and Management Science, 2 (Spring): 3-21.

Tozzi, Jim. 2011. “OIRA's Formative Years: the Historical Record of Centralized Regulatory Review Preceding OIRA's Founding,” 63 Admin. L. Rev. (Special Edition) 37.

Viscusi, W. Kip and Joseph E. Aldy. 2002. “The Value of a Statistical Life: A Critical Review of Market Estimates Throughout the World," Harvard Law School John M. Olin Center for Law, Economics and Business Discussion Paper Series. 392.

https://lsr.nellco.org/harvard_olin/392

Wagner, Wendy. 2009. “The Clean Air Interstate Rule's Regulatory Impact Analysis: Advocacy Dressed up as Policy Analysis," in REFORMING REGULATORY IMPACT ANALYSIS at 56, eds. Richard Morgenstern, et al., Resources for the Future Press.

Wagner, Wendy. 2010. “Administrative Law, Filter Failure and Information Capture,” Duke Law Journal. 59: 1321-1432.

Weber, Edward P. and Anne M. Khademian. 1997. "From Agitation to Collaboration: Clearing the Air through Negotiation," Public Administration Review, 57 (September): 396410."

Weiss, Debra Cassens. 2018. "Auer Deference Precedent Targeted by Business Groups May be Overturned by SCOTUS," National Law Journal, 10 December.

Weiss, Rick. 2004. “'Data Quality Law' is Nemesis of Regulation," Washington Post, 16 August 
Whitford, Andrew B. 2005. "The Pursuit of Political Control by Multiple Principals," Journal of Politics, 67 (February): 28-49.

Whitford, Andrew B. 2014. "Information and Uncertainty in Policy Implementation: Evidence from the Implementation of EPA Waivers," Journal of Public Administration Research and Theory, 24: 267-288.

Wilson, James Q. 1980. The Politics of Regulation. New York: Basic Books.

Wood, B. Dan and Richard Waterman. 1994. Bureaucratic Dynamics: The Role of Bureaucracy in a Democracy. Boulder: Westview Press.

Yackee, Susan Webb. 2006. "Sweet Talking the Fourth Branch: TheInfluence of Interest Group Comments on Federal Agency Rulemaking," Journal of Public Administration Research and Theory, 16:103-124.

Yackee, Susan Webb. 2014. "Reconsidering Agency Capture During Regulatory Policymaking," in Preventing Capture: Special Interest Influence in Regulation, and How to Prevent It. Eds, Daniel Carpenter and David Moss. Cambridge, UK: Cambridge University Press, 292-325.

Yackee, Jason Webb and Susan Webb Yackee. 2006. "A Bias Towards Business? Assessing Interest Group Influence on the U.S. Bureaucracy," Journal of Politics, 68 (February): 128-139.

Yackee, Jason Webb and Susan Webb Yackee. 2010. "Is Agency Rulemaking 'Ossified'? Testing Congressional, Presidential, and Judicial Procedural Constraints," Journal of Public Administration Research and Theory, 20: 261-282.

Yackee, Jason Webb and Susan Webb Yackee. 2012. "An Empirical Examination of Federal Regulatory Volume and Speed, 1950-1990," George Washington Law Review, 80: 1414-1492. 
Figure 1: State AG Environmental Lawsuits Brought Against the Federal Government

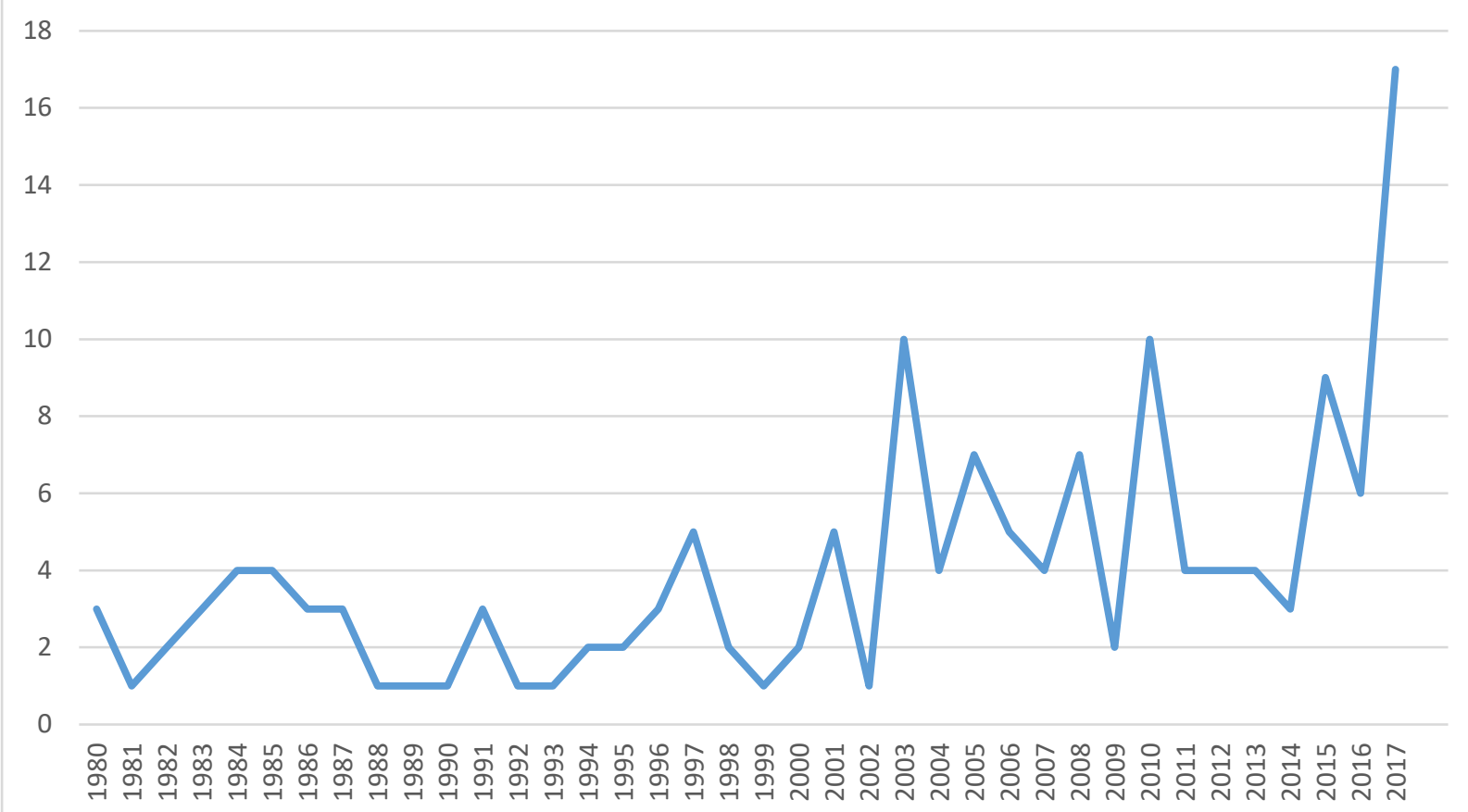

